\title{
Ontogenetic Development of the Immune Response in the Marine Teleost Sebastiscus marmoratus
}

\author{
Teruyuki Nakanishi* \\ (Accepted August 15, 1985)
}

\begin{abstract}
The functional capacity of the immune system was studied in the young rock fish. Two month-old fish are able to mount an antibody response against sheep red blood cells (SRBC), while this capacity is lacking or very low, even if present, in fry aged 1 month. Following immunization at the age of 1 month, the fish failed to induce an anamnestic response on reimmunization at 2.5 months after the first injection. Their reactivity to SRBC reached a similar level to that of the adult at the age of 3 months, although circulating antibody decreased more quickly than in adults. Fish as young as 1.5 months were capable of eliciting an allograft response in the same fashion as adults, measured by eye transplantation. Three month-old fish reject allografted scales more rapidly than adults. Comparison between normal and dwarf fish revealed that the immunological maturation was more dependent on the size rather than the age of the fish. The capacities ot mount both allograft rejection and antibody production were correlated with the development of the lymphoid organs. From these results, it is possible to say that the onset of immunological maturation occurs at about 1.5 and 2 months after birth, for allograft rejection and antibody production respectively.
\end{abstract}

In recent years, production of young larvae for marine ranching has been extensively performed all over the country. There have been considerable losses of larvae due to unknown disease, although great efforts have been devoted to increasing the rate of viability. Protection from disease in young fish is a big problem to facing mariculture in the future. However, knowledge on the defence mechanism in young fish is very sparse, especially in the marine teleosts which are generally more sensitive to changes in environmental conditions and which, as larvae, are smaller than freshwater fish.

Recently the maturation of the immune system has been described in salmonid and cyprinid fish, and some other species, ${ }^{1-B)}$ but few attempts were made to investigate the persistence of antibody production in the young stage. In the rock fish, the sequence of appearance of the lymphoid organs is different from that in the other fish reported. Namely, the thymus is not the first lymphoid organ to appear in the life of rock fish and only becomes evident one week after birth (3 days post-hatch), although the kidney and the spleen are present at the time of birth. ${ }^{7}$ The present study was performed to add some information about the functional development of the cellular and humoral immune system in the rock fish.

\section{Materials and Methods}

\section{Animals}

Ovoviviparous fish $S$, marmoratus were collected in Ago and Gokasho bay in the vicinity of our Institute. Pregnant females weighing 90-120 g were maintained in tanks with running sea water at $20 \pm 1^{\circ} \mathrm{C}$. Hatched larvae were born after 2 or 3 days stay in their mother's ovary. The time interval between fertilization and hatching was approximately 3 days at $20^{\circ} \mathrm{C}$. Feeding commenced at the time of birth with rotifer, this being supplemented at 20 days post-birth with artemia naupli or copepods. Young fish weighing 1.0 $7.0 \mathrm{~g}$ were fed small shrimps and krills. The fish were kept at $23 \pm 1{ }^{\circ} \mathrm{C}$ for the experiments.

\section{Immunization}

Sheep red blood cells (SRBC) in Alsever's solution were washed three times with phosphatebuffered saline (PBS, pH 7.2) and adjusted to $20 \%$ suspension. All animals were given three injections at 2 day intervals with $5-15 \mu \mathrm{l} / \mathrm{g}$ body. weight, intraperitoneally. A second injection of the same dose of SRBC was given 2.5 months after the primary immunization. Immunization was performed in April and May for the young and

* Inland Station, National Research Institute of Aquaculture, Tamaki, Mie 519-04, Japan (中西照幸：水産 庁滛殖研究所玉城分室). 
Table 1. Ontogeny of primary antibody response in young rock fish immunized with $15 \mu \mathrm{l} / \mathrm{g}$ per body weight of $20 \% \mathrm{SRBC}$ (i.p.) at $23^{\circ} \mathrm{C}$

\begin{tabular}{lcccc}
\hline \hline $\begin{array}{c}\text { Days after } \\
\text { birth }\end{array}$ & $\begin{array}{c}\text { Total length*1 } \\
(\mathrm{mm})\end{array}$ & $\begin{array}{c}\text { Body weight } \\
(\mathrm{g})\end{array}$ & $\begin{array}{c}\text { No. of } \\
\text { fish }\end{array}$ & $\begin{array}{c}\text { HA Titre*2 }\left(-\log _{2}\right) \\
\text { Mean }\end{array}$ \\
\hline 30 & $14-16$ & $0.02-0.03$ & 15 & ND $^{* 4}(6)^{* 3}$ \\
40 & $19-21$ & $0.07-0.12$ & 27 & ND \\
60 & $27-37$ & $0.25-0.83$ & 16 & $3.1 \pm 1.8(3)$ \\
60 & $\prime \prime$ & $\prime \prime$ & 12 & $1.1 \pm 0.9(5)$ \\
72 (normal) & $44-46$ & $1.2-1.5$ & 13 & $5.7 \pm 1.3(2)$ \\
72 (dwarf) & $27-29$ & $0.2-0.25$ & 5 & $1.0 \pm 1.2(2)$ \\
90 (normal) & $50-55$ & $2.0-2.7$ & 5 & $6.7 \pm 1.2(3)$ \\
90 (dwarf) & $30-42$ & $0.4-0.9$ & 5 & $6.4 \pm 0.6(2)$ \\
180 & $66-73$ & $4.9-6.5$ & 5 & $8.8 \pm 0.4(2)$ \\
\hline
\end{tabular}

*1 Weight and length were taken at the time of antigen injection.

*2 Titre was measured by the pooled plasma from 2 or 3 fishes.

* T Time intervals (weeks) between injection and bleeding are given in parentheses.

*4 Not detected

adult fish because of seasonal variation in the antibody production. For small larvae, a fine glass tube attached to the disposable needle (25G/ inch Termo, Tokyo) and microliter syringe (10 $\mu \mathrm{l}$ Hamilton company, Nevada, USA) was used for the injection, and $27 \mathrm{G}$ needle was used for the bleeding. Specific antibody titres to SRBC were determined using standard methods of haemagglutination in microtitre plates, while micropipette was used in place of diluter and dropper for a small amount of plasma less than $25 \mu \mathrm{l}$ from small fish. The fish were anesthetized with ethyl pamino benzoate $(100 \mathrm{mg} / \mathrm{l})$ prior to manipulation.

\section{Scale Grafting}

First set allografting and autografting of scales were carried out on adult, and young of older than 3 months. An estimation of graft survival was made by counting the number of melanophores on six reciprocal scale allografts and the average computed. When intact melanophores were broken down, the grafts were considered to be rejected.

\section{Eye Grafting}

In fry younger than 3 months old in which scales were too small for grafting, reciprocal exchange of the eye was performed to examine allograft reactivity. One side of the eye was exchanged among fish as a allograft by cutting the hemisphere and the nerve. The other side was autografted to the opposite side. Breaking down of melanophores and ctenophores on the iris, clouding of the lens, and falling off of the eye were used as criteria for assessing the survival of grafts.

\section{Results}

\section{Antibody Response to SRBC}

As shown in Table 1, no agglutinating antibodies were detected when fish were immunized at the age of 30 or 40 days after birth and the plasma analyzed 6 or 5 weeks after the first injection respectively. The fish elicited some quantity of antibody when immunized at 60 days old, and the plasma collected 3 weeks after the first injection. However, in the 60-day-old fish in which sera were analyzed 5 weeks after immunization, lower titres were observed. At the age of 3 months, fish elicited similar levels of peak titre to the adult, although the titre level decreased mote quickly than in adults (Fig. 1). The same aged fish (72 days old) were separated into two groups (normal and dwarf) according to the size, and the level of antibody titre was compared between the two groups. Only one of three samples from dwarf fish showed a lower titre, while normal fish were capable of eliciting a fairly high level of titre. At the age of 90 days, however, dwarf fish showed a high level of tire. So, there was no difference between normal and dwarf in their ability to produce antibody at this age or size (Table 1, Fig. 1). No anamnestic response was observed when fish were immunized at the age of 30 days and rechallenged 2.5 months after the first injection (Table 2).

\section{Development of Alloimmune Response}

Allografts were rejected within 4 to 5 days, more rapidly than in adults when scale grafting was performed at 3 to 5 months old (Table 3). Furthermore, eye allograft rejection was completed 


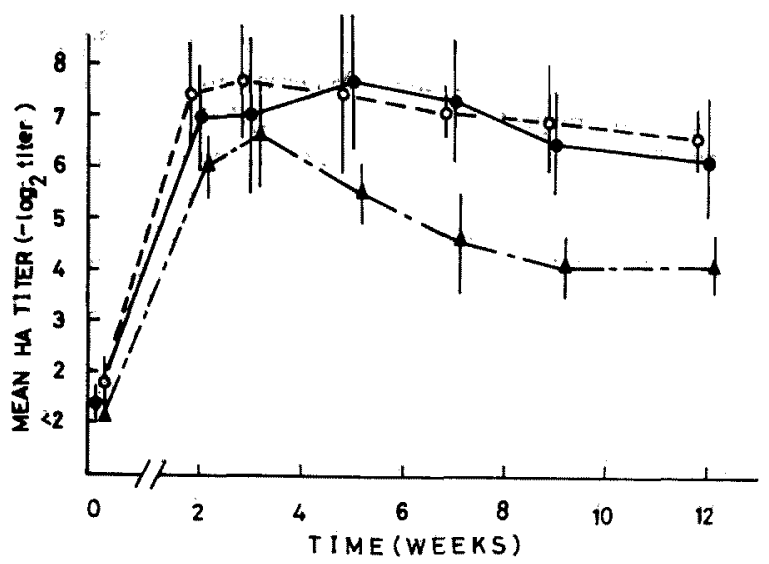

Fig. 1. Persistency of antibody production in young and adult rock-fish immunized three times with $5 \mu l$ per body weight (g) of $20 \% \mathrm{SRBC}$ (i.p.) at $23^{\circ} \mathrm{C}$

$\Delta-\Delta$ : three months old

$0-0$ : one year old

- two or three years old

Each point represents the mean response of seven fishes \pm SD (vertical bars).

Table 2. Secondary antibody response in young rock fish immunized with $15 \mu / / \mathrm{g}$ per body weight of $20 \% \mathrm{SRBC}$ at $23^{\circ} \mathrm{C}$

\begin{tabular}{ccccc}
\hline $\begin{array}{c}\text { Time of injection } \\
\text { (Days after birth) }\end{array}$ & $\begin{array}{c}\text { Total length } \\
(\mathrm{mm})\end{array}$ & $\begin{array}{c}\text { Body weight } \\
(\mathrm{g})\end{array}$ & $\begin{array}{c}\text { No. of } \\
\text { fish }\end{array}$ & $\begin{array}{c}\text { HA Titre }\left(-\log _{2}\right) \\
\text { Mean } \pm \text { SD }\end{array}$ \\
\hline 30 (1st response) & $14-16$ & $0.02-0.03$ & 15 & ND \\
$16)$ \\
108 (2nd response) & $54-66$ & $2.7-4.7$ & 7 & $8.2 \pm 0.6(2)$ \\
108 (control) & $54-61$ & $2.6-3.6$ & 7 & $7.5 \pm 1.4(2)$ \\
\hline
\end{tabular}

See footnotes of Table 1 for the description.

Table 3. Ontogeny of scale allograft reactivity in young and adult rockfish at $23^{\circ} \mathrm{C}$.

\begin{tabular}{cccc}
\hline \hline $\begin{array}{c}\text { Age } \\
\text { (months } \\
\text { after } \\
\text { birth) }\end{array}$ & $\begin{array}{c}\text { Total length Body weight } \\
(\mathrm{mm})\end{array}$ & $\begin{array}{c}\text { R.T. } \\
\text { (days) }\end{array}$ \\
\hline 3 & $39-48$ & $0.8-1.5$ & $4.4 \pm 0.8$ \\
4 & $60-68$ & $3.0-5.0$ & $3.8 \pm 0.4$ \\
5 & $66-74$ & $4.8-6.7$ & $5.0 \pm 0.0$ \\
12 & $120-145$ & $24-46$ & $6.0 \pm 0.0$ \\
\hline
\end{tabular}

* Rejection time. Mean of five fishes.

within 8 days in the same fashion as in the adult, at the age of 1.5 and 2 month-old fish.

\section{Discussion}

It is generally agreed that the ability to react to histoincompatible tissue develops early in teleost fish. Young fry could reject allografts at 23 days post fertilization in Xiphophorus maculatus at $20^{\circ} \mathrm{C},{ }^{8)} 16$ days post hatching in Cyprinus carpio at $20-22^{\circ} \mathrm{C},{ }^{3)}$ and 14 days post hatching in rainbow trout at $14^{\circ} \mathrm{C}{ }^{\circ}{ }^{\circ} \quad$ The present study showed that 1.5 month old fish could reject the allografted eye in the same fashion as in adults. This functional capacity of alloimmunity is coincident with the development of the thymus, which is considered to be an important organ for the maturation of the immune system. Namely, small lymphocytes first appeared in the thymus at the age of 3 weeks after birth and increased rapidly in number. At 1.5 months post-birth, the thymus was fully developed and at its maximum ratio of thymus weight to body weight. ${ }^{7}$. These findings are similar to those found in the rainbow trout, ${ }^{6)}$ and carp. ${ }^{9)}$ Both Tatner and Manning in the rainbow trout and Botham and Manning in the carp have shown that the maturation of the thymus, lymphocytic differentiation in the kidney, and the presence of small lymphocytes in the peripheral blood are correlated with the development of alloimmune reactivity.

As to rapidity of allograft rejection, young fish at 3 to 5 months of age rejected allografted scales 
more rapidly than in adults, although most studies previously reported in fish showed that rejection times were inversely related to the age of the fish. ${ }^{1,6,8,10)}$ These findings with respect to the vigorous response of allograft rejection in young fish may be attributed to the well developed thymus which is at its maximum thymus to body weight ratio, and the strong response in cellular immunity may compensate for the humoral immune system which is not fully developed at this age.

The present study in rock fish indicates that young fish of 2 months old are capable of eliciting a humoral immune response, although the level of titre is lower than in adults. These results are consistent with the recent studies in carp, ${ }^{5)}$ rainbow trout $^{8)}$ and tilapia, ${ }^{1)}$ although differences among species and antigens used are clear to some extent. Furthermore, young fish of 3 months old attained a similar level of antibody production to the adult, although the duration period was shorter than in the adult. This functional capacity in antibody production is also well correlated with the development of the lymphoid organs. Small lymphocytes are present 4 weeks after birth in the pronephros, and after 6 weeks in the spleen. ${ }^{7)}$ A marked increase in lymphoid cells in both the pronephros and mesonephros, which are the major antibody producing organs in this fish, ${ }^{11}$ was observed at 3 months of age.

In the secondary response, the induction of immunological tolerance has been reported in salmonid and cyprinid fish. In rainbow trout, fish injected at 21 days after hatching and tested for their humoral antibody responses 8 weeks after immunization were found to be capable of reacting to a bacterial antigen, but not to human ganma globulin (HGG, a soluble antigen). Furthermore, when tested for their memory responses by secondary immunization 8 weeks after the primary injection, followed by serum antibody titration 8 weeks later, the fish injected with $\mathrm{HGG}$ in their primary immunization remained unresponsive to HGG, although control fish and fish which had previously received BSA were able to respond to this antigen.") In carp fish aged 4 weeks were unable to mount a plaque-forming cell response to SRBC. Furthermore, when these fish were reimmunized 3 months later they still failed to respond, although animals which received their first injection of SRBC at 4 months of age showed normal anti-SRBC reactivity. ${ }^{5)}$ In the present study with rock fish, neither anamnestic nor tolerogenic responses were observed when fish received a first injection of SRBC at 30 days of age, and were then reimmunized 2.5 months later. Whereas in experiments with the fish, Sebastes pachycephalus, a closely related species to Sebastiscus marmoratus, fish which received a first injection of SRBC at 25 days after birth $(13 \mathrm{~mm}$, $0.03 \mathrm{~g}$ ) and were then reimmunized 5 months later failed to respond, although animals receiving their first injection of SRBC at 6 months of age showed normal anti-SRBC reactivity (unpublished data). Therefore, the critical period for tolerance induction may be before 1 month of age in this species.

Concerning the effect of the size and age on the development of the immune system, the present study showed that size is an important factor in determining immunological maturation, rather than age. From these results, it is conoluded that the critical size and weight to elicit antibody against SRBC is $27 \mathrm{~mm}$ total length and $0.25 \mathrm{~g}$ body weight ( 2 months old) respectively in this species of fish.

\section{Acknowledgements}

The author would like to thank to Dr. M. F. Tatner, Institute of Aquaculture, Stirling University, Scotland for critically reading the manuscript, and Mr. A. Tsujigado, The Fisheries Research Institute of Mie Prefecture for his kind advice on fry production.

\section{References}

1) K. Sailendri: Ph. D. Thesis, Madurai University, Madurai, India, 1973.

2) G. T. Rijkers and W. B, van Muiswinkel: in "Developmental Immunobiology" (ed. by J. B. Solomon and J. D. Horton), Elsevier/North Holland Biomedical Press, Amsterdam, New York and Oxford, 1977, pp. 233-240.

3) J. W. Botham, M. F. Grace, and M. J. Manning: in "Phylogeny of Immunological Memory" (ed. by M. J. Manning), Elsevier/North Holland Biomedical Press, Amsterdam, New York and Oxford, 1980, pp. 83-92.

4) M. J. Manning, M. F. Grace, and C. J. Secombes: Dev. Comp. Immunol., suppl. 2, 75-82 (1982).

5) J. J. A. Van Loon, R. van Oosterom, and W. B. van Muiswinkel: in "Aspects of Developmental and Comparative Immunology I." (ed. by J. B. Solomon), Pergamon Press, Oxford, 1981, pp. 469-470.

6) M. F. Tatner and M. J. Manning: Dev. Comp. Immunol., 7, 69-75 (1983).

7) T. Nakanishi: Ph. D. Thesis, Hokkaido University, Hakodate, 1983.

8) K. D. Kallman and M. Gordon: Ann. N.Y. 
Acad. Sci., 71, 307-318 (1957).

9) J. W. Botham and M. J. Manning: J. Fish Biol., 19, 403-414 (1981).

10) E. L. Triplett and S. Barrymore: Biol. Bull.,
118, 463-471 (1960).

11) T. Nakanishi: in "Proceedings of the First International Congress on Pathology of Marine Aquaculture" (in press), 1985. 